\title{
ECONOMY AND PARA-FISCAL LEVIES IN BOSNIA AND HERZEGOVINA
}

\section{Hasan Mahmutović ${ }^{1}$}

Faculty of Economics, University of Zenica
Review paper

DOI: $10.21554 / \mathrm{hrr} .041712$

Received: 13.03.2017

Accepted: 08.04.2017

\begin{abstract}
The system of para-fiscal levies implies different types of benefits or compensation and payment of citizens and companies for the use of goods or services of state administration which are para-fiscal sources of income of the state. The main characteristics of para-fiscal levies are: they do not originate from all tax payers, but only from members of certain social groups that are linked to some common economic or social interests; they are not part of the budget funds and not regulate them fiscal authorities; they have the character of destined public revenues, as they regularly represent a dedicated revenue whit which a specific task of economic or social character would be solved; they represent a secondary tax levy, which means that they exist along with the country's tax levy, to draw funds from the same economic resources and to have almost the same economic effects, as well as the collection of taxes; they shall be paid on the basis of laws and decisions or decision of the competent authorities (general obligation) or by contract (a specific levy, ie. an individual obligation); they shall be paid in the event of use of property of general interest and / or services of state administration; they represent giving of money, which is always direct, ie. giving cash on the basis of the decision and with the issuance of a receipt of payment (receipt from a box office or bank). Para-fiscal levies should be understood as fees that economic operators and citizens pay for the use of certain goods or services. These are not taxes and they do not serve to fill the budget. However, in Bosnia and Herzegovina the biggest part of para-fiscal levies is used as a parallel budget revenue, as revenue for the operation of the costly administrative apparatus. A large number of studies on para-fiscal levies in Bosnia and Herzegovina showed that they have a negative impact on economic growth and development. Basically para-fiscal levies, for business entities at higher levels of government, can be grouped into 25 fee and tax groups, and in 9 groups of special fees and membership fees (federal administrative fees, federal court fees, water fees, road fees, forest fees, environmental fees, fees for protection against natural and other disasters).
\end{abstract}

Keywords: economy, para-fiscal levies, law, Bosnia and Herzegovina

\section{RESEARCH}

Entrepreneurs in Bosnia and Herzegovina have the largest burden, in comparison with countries of the European Union and with neighboring countries, and one of the key objectives of the Reform Agenda regarding improvement of the business environment in Bosnia and Herzegovina is to minimize the parafiscal fees.

\section{FEES IN THE PUBLIC REVENUE SYSTEM}

Fees in financial theory imply to income which are money equivalents for services of public authorities or other public law authorities to citizens or legal persons. Unlike taxes, which represent the obligation of payment that the state collects by the force of its fiscal sovereignty, without a direct compensation, fees are compensations for the direct services that the state makes to the taxpayers. This service can be: freely chosen by the payer and imposed by regulations to taxpayers.

\footnotetext{
Correspodence to:

Hasan Mahmutović, Faculty of Economics, University of Zenica

E-mail: hasanmahmutovic@hotmail.com
} 
The ways of charging fees can be direct and indirect. Direct collection of the fees occurs when the fee is paid in cash, with the issuance of receipts. Indirect taxes are collected in the case when purchasing court fees at authorized places, usually in the form of revenue stamps.

Fees are, usually, divided: according to authorities who prescribed fee obligation (central state bodies and close social and political communities), according to authorities who carry out certain services (administrative, customs, consular, cadastral, legal, judicial, clerical, etc.), according to the time of payment: fees which are paid in advance; fees which are paid retrograde, according to the number of executive services: arbitrary fees (for services that round up a entity) and individual fees and according to the purpose of spending: fees to cover social needs without determined purpose of spending the funds, fees for which the purpose is pre-determined.

There are other types of fees, for example: general and special, followed by constant and variable, and so on, administrative fees, court fees, communal fees, registration fees and local fees (Jelčić, 2001).

Income from all types of fees belongs to the budgets. Fees are government revenues in which the voluntariness is present, but, in many cases, it is relative voluntariness. For example, citizens have the choice whether they will register their vehicle or not, but, in any case, they will not be allowed to use non-registered vehicles.

Compulsion as an element while paying fees includes: an obligation to pay the fee and its amount is determined by a state authority, that some rights may be exercised only after the taxpayer initiate a proper process and that unpaid obligations (fees) will be collected forcibly

The amount of fees is determined by the estimated amount of costs that state authority has while carrying out required services.

The payers are citizens and legal persons who turn to the competent authority with a request to carry out some (abstract) services. The amount of fees depends on whether the provided service is of exclusive interest and is used only for the seeker of this service (payer of fees), or there is a general interest (interest of society) to perform the required service. If not only an individual is interested for the execution of certain services, but also a public authority, the amount of fees should be lower than effective expenses. Public interest sometimes can be so accented that the legisla- ture provide a fully release of payment of fees.

The state in some cases determines the amount of fees on the basis of their negative attitude towards some form of activity so that, in this case, the amount of fees is formed beyond the actual costs. Thus, the fees for court proceedings are determined by the value of the dispute, by duration, by the number of acts and the like, and in an effort to discourage irrational conduct of court cases if there is a high probability that there is justification for conducting the process, which increases public expenditure whit which the judiciary is financed by.

There are a few principles (principles) that should be respected when introducing fees. The fee tariff, namely: should be general and not depend only on the type and size of services, should not be complicated and should include services of authorities in general

As the tax system, the fees system is based on respecting certain principles. These are: the principle of legality (whereby the charges can be imposed only by law or by adequate regulations), the principle of generality (the requirement that the charges, as well as taxes and other fiscal revenues, are determined for all in advance, rather than case by case), the principle of simplicity (the fee tariff is of a technical nature and should be simple, and to easily and accurately allow the payment of the prescribed fee), the principle of cumulating fees (this means that for the same file or action it is not possible nor allowed to charge a fee cumulatively by several public legal entities).

In the terminology of fee terms, significantly different terms are appearing from the terms of taxes: the subject of fees involves actions of a state authority for which fees are prescribed by law or a court decision, the payer of the fee is a citizen or legal person on whose behalf the requested action provided according to the fee tariff, that is, for whom actions were undertaken for whose conduct an obligation to pay fees is prescribed, the fee base is the value of the service which is used for calculating fees, the fee rate is a determined amount (expressed in percentage, fixed or arbitrarily) which the fee payer has to pay per base unit, fee tariff is a systematically arranged list of actions, descriptions of use, certain rights, services, objects and the like, for whose execution, or use, a fee is charged, fee liberations can be personal and concerned. Personal liberation are usually prescribed by social reasons (bad material position of the fee payer), and the fees system is a set of all fee forms that are in use in a specific country. 
LEGISLATIVE FRAMEWORK LOTTERY GAMES IN FEDERATION OF BOSNIA AND HERZEGOVINA AND ITS IMPLICATIONS TO CANTONS AND MUNICIPALITIES

\section{Law on lottery games}

The Law on Lottery Games was adopted by the Parliamentary Assembly of the Federation of Bosnia and Herzegovina on 15.1.2002 (Official Gazette of F Bosnia and Herzegovina 10/02), and amendments were made on 8.7.2010 (Official Gazette 40/10). The content of this law which is the subject of research and analysis is given in the next section of the paper.

\section{General provisions}

\section{Article 1:}

This law regulates: conditions, ways and entities of organizing lottery games, types of lottery games, basic principles of rules and allocation of revenue from lottery games, establishment, legal status, governance and management of the Lottery of Bosnia and Herzegovina, fees for organizing lottery games, penalties for violations and ther issues of importance regarding lottery games.

\section{Article 3:}

Lottery games are divided into classical and special lottery games. Classic lottery games are games involving a larger number of participants with the intention to be the only winner or partial winners of the pre-defined fund, which are: Lottery: commodity, monetary, mixed, express lottery and instant lottery, Lotto, Keno and other variants of the game, Sports forecast-Toto, Slot machine games, TV Bingo and Bingo in an enclosed space.

Special lottery games are games where the individual himself opposes the organizers and expects a gain depending on the amount of their own wager and rules of the game, in which the fund is not predetermined, which are: casino games, slot machine games in special clubs and games with other devices with multiple roles and earnings (multiplayer), betting on various results and events and the like.

\section{Article 6:}

Lottery games from Article 3 of this law are organized on the basis of this law and approvals.

Article 7:

Special lottery games can be organized by: Lottery of Bosnia and Herzegovina under the conditions provided by this law and the companies that are registered only for specific individual lottery games provided by this law on the basis of approvals.

Article 9, 10 and 11:

Various games are not considered as lottery games according to this law in which the player can gain profit, followed by so called pyramid games and lottery games via the internet and which are prohibited in the territory of Federation of Bosnia and Herzegovina.

\section{Lottery of Bosnia and Herzegovina}

\section{Article 19-21:}

These are related exclusively to the Lottery Bosnia and Herzegovina as a limited liability company (Ltd.) with a particular interest for the Federation, whose status, authorities, method of work and other matters are regulated by this law in a special way in relation to other legal entities who organize lottery games. It is interesting that these provisions (amended Article 7 with new paragraphs 3,4,5,6,7 and 8) regulate in detail the allocation of resources of Lottery of Bosnia and Herzegovina (of which 50\% belongs to the Federation of Bosnia and Herzegovina).

\section{Classical lottery games}

Article 22-49:

They relate to the classical lottery games, game rules, conditions for organizing games, funds, payment of winnings and other (generally for all classical games), and then separately for each of the types of games described in Article 3 of this law which are Lotto (Article 33), Lotto-Keno and their other variants (Article 39-44), TV Bingo (Article 45) and Bingo in an enclosed space (Article 46- 49).

\section{Special lottery games}

Article 50-55:

These Articles contain provisions on the obligation to making the rules of the game, provisions for funds, provisions for operating licenses and more. Is prescribed that slot machine games must be programmed to provide a minimum payout of $70 \%$ of the total wager over a period of three months (Article 53) and that the difference between the total daily deposits and withdrawals represents a gain or loss (Article 55). 
Article 56-68 (casino):

These articles regulate in detail issues exclusively related to the games in casinos as a special type of lottery games.

\section{Article 71:}

These games are organized by commercial companies incorporated in the Federation of Bosnia and Herzegovina, with the approval of the Ministry, and which meet the following conditions: that it is registered for organizing these types of lottery games, that it is the owner of the slot machine, that an adequate space to accommodate at least 20 of slot machines is provided, and that it is not located near religious, historical and educational institutions and facilities, that rules for these lottery games are given, that the slot machine has a certificate that it is constructed and configured so to provide a profit of $70 \%$ of the total wager, which does not include in betting "higher-less", evidence of an authorized legal entity established on the open online network connected with the Tax Administration Central Office in Sarajevo (this condition is prescribed by amendments to the law, Official Gazette of Federation of Bosnia and Herzegovina 40 / 10.), in addition to the conditions from the previous paragraph the applicant is subjected to verification by the Ministry in terms of locations of the office building in which to put the slot machines, ownership over the machines as well as the legality and regularity of the trading records and behavior.

The solution for the issue of authorization is also the approval of the Ministry of the acts from paragraph 2 of this Article.

\section{Fees for lottery games}

Article 86:

The provisions of this Article have; in fact, the character of regulation which introduced the tax liability and establishes the tax scale, regardless of that it is referred to as compensation. This Article provides:

For issuing licenses for organizing lottery games, the approval of lottery game rules, the extension of license to organize lottery games and for opening new locations a compensation should be paid.

The fee from paragraph 1 of this Article is the revenue of Federation of Bosnia and Herzegovina, and is paid for:
1. Permission for organizing games:

a) on slot machines in special clubs

- permission to establish a club 50,000.00 KM

- for 20 slot machines 20,000.00 KM

- for every additional slot machine $500.00 \mathrm{KM}$

- for extension of permission 10,000.00 KM

b) in casinos

- permission to establish a casino $500,000.00 \mathrm{KM}$

- for approval of rules of one game $1,000.00 \mathrm{KM}$

- for approval of rules of work of the casino 1,000.00 KM

- for extension of permission $100,000.00 \mathrm{KM}$

c) in betting shops

- for work permission 50,000.00 KM

- for approval of rules of one game 1,000.00 KM

- for establishing of an additional location 10,000.00 KM

- for extension of permission 10,000.00 KM

d) Bingo in enclosed space

- for permission to organize games 5,000.00 KM

- for approval of rules of one game $500.00 \mathrm{KM}$

- for extension of permission 1,000.00 KM

Without evidence of payment of compensation from paragraph 2 of this article, a permission may not be granted and it cannot start to work. Fees from paragraph 1 of this Article do not apply to the Lottery Bosnia and Herzegovina.

\section{Supervision}

\section{Article 87:}

Supervision over the implementation the provisions of this law are done by the Ministry of Finance.

The analysis of the Law on Lottery Games of the Federation of Bosnia and Herzegovina gives a basis for some general observations and conclusions, which are:

1. The adoption this law is based on the Constitution of the Federation of Bosnia and Herzegovina, the provisions of Article III.1. as amended in Amendment VIII, which determined exclusively jurisdiction to the Federation of Bosnia and Herzegovina. Paragraph d) of this article specifies that the Federation of Bosnia and Herzegovina has exclusively jurisdiction over: decisions concerning the regulation of finances and institutions of Federation of Bosnia and Herzegovina and the fiscal policy. 
2. The Federal law on lottery games has the characteristics of a complete law as it regulates issues of organization and preparation of lottery games, especially classic games (Lottery etc.), and special games (on slot machines and in clubs), including the payment of the prescribed duties (fees) for equipment and activities.

3. It can be said that this law gave authorization to the authorities of Federation of Bosnia and Herzegovina of exclusive competence, so that there is not left any space for the adoption of a law on the same matter at lower levels of government, what the case would be if there was a shared jurisdiction between the Federation of Bosnia and Herzegovina and the cantons.

4. The law regulates one specific area with a number of special characteristics in terms of activities, equipment, entities (the organizers of games, etc.), so that normative solutions are adapted to these specific characteristics. By this the law can be considered as a special law (lex specialist) in relation to other laws of general nature (lex generals). As such, the law on lottery games has a priority over other laws in case of conflict of jurisdiction, or validity of specific regulations.

5. In relation to the specific provisions of the law remarks can be placed regarding Chapter V, Article 86. - fees for organizing lottery games, with a focus on the provisions under Clause I.a) the second and third indent. These points determined the amount of fees for organizing lottery games on slot machines and in the special clubs with an amount of 20,000.00 KM for 20 slot machines (1,000.00 KM per device), and $500.00 \mathrm{KM}$ for each additional slot machine. These obligations are paid annually and have permanent validity, which gives them the characteristic of taxes, but not fees as the law states. Fees are actually prescribed in the first and fourth indent of this article (50,000.00 KM and 10,000.00 KM), because they are being paid just once as the equivalent of a permission to start work and extension of its validity, and therefor are not questionable in this regard.

6. Regardless of whether it is a reimbursement or tax, it is a duty to pay by a business organization - organizer of lottery games, so we can ask the question if this is justified from the point of double taxation since these entities pay taxes for the profit generated by the same games and the same machines. In addition, on the same basis the same entities are obliged to pay property taxes (for slot machines) by cantonal regulations, and even communal fees (for organizing the games) by municipal regulations.
Obligations of subjects are the same and there is one actual basis for imposing duties, but the duties are described differently and differently enacted on many levels.

\section{Communal fees \\ Legal origins of communal fees}

Fees are a form of revenue collection of the state that started to develop already in slavery and in feudal states. The obligation to pay in the present sense of the word is most closely associated with the development of public administration. Over time there has been a broadening of fee payment obligations and increase of their amount. However, by widening the circle of taxpayers, the number of tax forms, and in particular the tax burden in the total revenue of the state revenues collected by charging fees is becoming smaller and smaller.

Fees have a number of common elements with other financial instruments of revenue collection of the state. Thus they have similarities with taxes and contributions, but they also differentiate from these forms of state income. Fees are cash revenue of the state. Fees base their legal foundation on the following legal sources:

1. Law on Administrative Fees, published in the "Official Gazette of BiH", No. 5/95;

2. The law on court fees, published in the "Official Gazette of $\mathrm{BiH}^{\prime \prime}$, No. 5/95;

3. Law on Communal Fees, "Official Gazette of BiH" No. 7/97;

In our tax system, fees are treated as charges for certain services carried out by state authorities and authorized organizations and institutions, and belong to a system of income in Bosnia and Herzegovina. Classification of taxes in our system can be made according to different criteria, and the most used division is:

- by case which is subjected to fees (administrative, communal as a special administrative fee and court fees);

- by authority to introduce fees (each sociopolitical subdivision introduce their fees, municipalities are authorized to introduce administrative, judicial and communal fees, the cantons and higher authorities may impose administrative and court fees, and the state of Bosnia and Herzegovina for services of its jurisdiction can introduce administrative, consular, judicial, customs fees and fees on foreign cars);

- and by the way of collection (those who are paid in cash-direct payment and those charged with administrative fee stamps-indirect payment). 


\section{Municipal regulations on communal fees}

The performed analysis of municipal regulations on communal fees provides the basis for the following findings and conclusions:

1) It can be said that the responsibility of municipalities to adopt regulations on communal fees is indisputable because it is based primarily on the constitutions of cantons, and then on the constitution of the Federation of Bosnia and Herzegovina, and that the decisions taken by the competent authority, or municipal council as the legislative body of the municipality, are justified although the states in the preamble are inadequate.

2) However, whether these legislations in general or just in certain parts (provisions) are statutory or constitutional, presents a separate issue. According to the constitutional system and the applicable law, it is evident that the Federation of Bosnia and Herzegovina has exclusive competence by the federal constitution for certain issues in the field of taxes and other duties. In this section it is authorized to make laws and determine and implement fiscal policy. On this basis the Federation of Bosnia and Herzegovina, among other things, adopted the Law on lottery games which regulate this matter in detail, and prescribes payment of fees for the operation of companies whose activities are organizing lottery games. With this law, as it is evident, permanent charges for work with an annual amount according to the number of slot machines for lottery games are prescribed, whit which this matter is exhausted, and the cantons, cities and municipalities do not have the basis for the fulfillment of the obligations of these legal entities. In addition, the law on lottery games is a special law only by this matter (lex specialist), and as such has an advantage over other general laws of the Federation of Bosnia and Herzegovina (lex generalis), especially under the laws of a lower level.

3) The fact that the courts have identical points of view supports this conclusion, both the regular and the constitutional court of the Federation of Bosnia and Herzegovina because they have convicted in specific cases on the grounds in this sense. With these verdicts some provisions of cantonal laws and municipal decisions were determined as unconstitutional.

\section{RESULTS}

For the analysis of court cases related to communal fees 14 judgments of the Constitutional Court of Federation of Bosnia and Herzegovina were taken, and a larger number of judgments of the cantonal courts. Given the stated number of analyzed judgments, as well as a larger number of other judgments that have been published in the Official Gazette of Bosnia and Herzegovina, it could be said that the results of these activities are the case-law on the application of obligations for lottery games in cantons and municipalities. The cantonal judicial and constitutional judgments point out that the type of activity cannot be a relevant criterion for prescribing different amount of fees for a prominent company and label, and in the following municipalities: Zenica, Visoko, Zavidovići, Doboj Jug, Kakanj, Žepče, Ljubuški, Odžak, DomaljevacŠamac, Banovići, Gračanica, Kiseljak, Novi Travnik, Gornji Vakuf-Uskoplje, Bugojno.

A group of ogranizers of lottery games, Premier World Sports doo Čitluk, Bet-Live doo Vitez, Pet plus doo Vitez, Sport plus doo Novi Travnik, Premier Sports doo Citluk, Hartrick doo Vitez, Zmajevi doo Zenica has sent an objection to City Council of Zenica on 12.13.2016 on the Draft decision on amendments to the Decision on communal fees of City of Zenica.

The Constitutional Court of Federation of Bosnia and Herzegovina is already three times (2006., 2009., 2014.) declared the decision on communal fees of municipality of Zenica as unconstitutional, for the violation of the right for equality before the law, since the criteria for prescribing fees to highlight the label of company was based on the type of activity that the legal subject conducts. The activities of lottery games and betting shops are classified as legal persons and entrepreneurs for which a communal fee of 3,000.00 $\mathrm{KM}$ is determined, which is the rough way of discriminating the respective activities.

The proposed draft of amendments to the Decision on communal fees, it is not aligned with the Constitution of the Federation of Bosnia and Herzegovina, but the discrimination is taken to the next level with the proposal that fee would be $50,000.00 \mathrm{KM}$. Adopting the Draft decision, a crime is committed under article 241 of the Criminal Law of the Federation of Bosnia and Herzegovina, which is violation of equality in the exercise of economic activity. 
It is essential to eliminate the criterion of company activity from the decision for determining the company fee.

\section{CONCLUSION}

From the above it can be concluded that it is necessary to work on improving laws and bylaws in this whole industry, but first the special law on lottery games, in order to allow normal operation of the organizers of lottery games, but also the legal collection of fiscal income.

It is quite clear that the constitutional framework and international conventions and standards are the basis for legislation, with understandable respect for science and profession in this field.

The analyzed cases indicate that the amount of taxes provides the basis for the conclusion of an unbearable fiscal burden because the amount of obligations threatens the very substance of fixed (permanent) as- sets that generate income in the relevant industry.

All this indicates that the current legal framework hinders normal operations of business organizations, concerned industry, more than they contribute.

Such situation cannot be qualified as justified from a social and economic point of view, or that it is constitutional and legitimate and lawful, which inevitably leads to the changing of the status of the generalinterest and social interest of each of the concerned entities.

\section{REFERENCES}

Jeličić, B. (2001). Javne finansije, Zagreb, str.189

Raičević, B. (2005). Javne finansije, Beograd, str. 249

Zakon o igrama na sreću, Službene novine F BiH, br.1/2, Sarajevo, 2002.

Zakon o Izmjenama i Dopunama Zakona o igrama na sreću, Službene novine F BiH, br. 40/10, Sarajevo, 2010.

Zakon o igrama na sreću, Službene novine $\mathrm{F} \mathrm{BiH}$, br.48/15, 60/15, Sarajevo, 2015. 